\title{
The Matthean characterisation of Jesus by John the Baptist
}

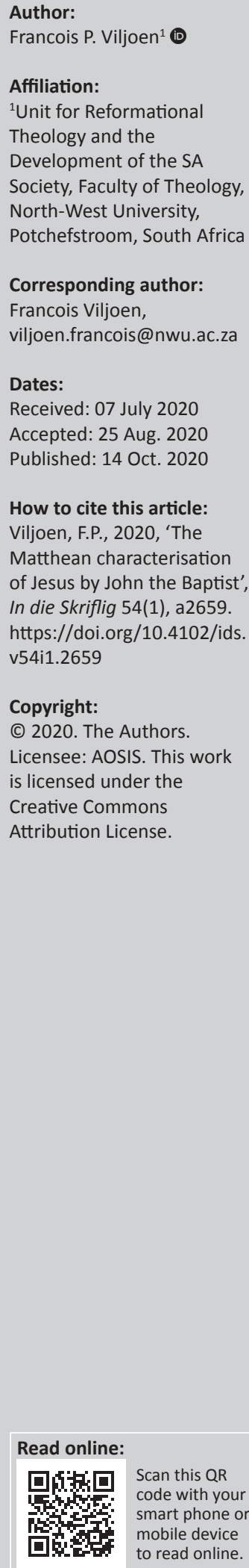

It goes without saying that Jesus is the protagonist, the main character, in the Gospel narratives. Much of this characterisation is achieved by presenting his speech and actions. As his speech and actions occur in relation to other major and minor characters in the narrative, much of the characterisation is achieved by presenting the interaction between Jesus and these other characters. Among humans, John the Baptist acts as Jesus' main supporting character. He is portrayed as a reliable witness to Jesus' life, of the one to come. This article focusses on the characterisation of Jesus in the First Gospel, based on examining his relation to and interaction with John. Passages in this Gospel narrating the relation and interaction between John and Jesus are explored to identify Jesus' character traits. These are multi-faceted and relates to Messianic expectations described in Jewish writings. Yet, the Matthean narrator argues that Jesus surpasses these expectations - even those of John the Baptist himself.

Keywords: characterisation; narrative criticism; Jesus; John the Baptist; witness; Messiah; Matthew; Gospel.

\section{Introduction}

In their characterisation ${ }^{1}$ of Jesus, the Gospels ${ }^{2}$ do not provide descriptions of Jesus' outward appearance. Rather, he is characterised through statements by the narrators about his inner personality. Besides these statements by the narrators, much of his characterisation emerges from his own speech and actions. His speech and actions occur in relation to other major and minor characters in the narrative, with the result that much of it is achieved by presenting these interactions between Jesus and the other characters. The whole plot is orientated towards Jesus, while all characters and incidents are viewed in relation to him. He is surrounded by supporting characters, while he is constantly met by antagonists.

All four Gospels describe John the Baptist as a significant figure. In their narratives, the Baptist acts in support of Jesus, the protagonist. Among the interactions between Jesus and supporting and opposing characters, those between him and John play a substantial role in characterising him.

This article focusses on how this interaction presents the characterisation of Jesus in the First Gospel, Matthew. In this Gospel, material about John predominates in chapters 3 and 11. Meier (1980:387) pointedly refers to Matthew 3 as 'the Baptist's view of Jesus and himself' and to the first half of Matthew 11 as 'Jesus' view of the Baptist and himself'. In addition to these two chapters, shorter references to the interaction or relation between Jesus and John are made in Matthew 14,16, 17 and 21. This article explores all these passages that emphasise the relation and interaction between Jesus and John. While verses are explored in which explicit interaction between Jesus and John is narrated, these verses are read within their immediate contextual narrated scenes. While attending to Matthew's narrative, comparisons are made with parallel passages in the other Synoptic Gospels to further sharpen the discussion of the Matthean narrator's unique contribution.

1.The 'story' of a narrative includes events, setting and characters (Kingsbury 1986:9; Powell 2009:45-52). Authors bring characters to life by way of characterisation (Anderson 1994:78; Powell 1990:51; Tolmie 1999:41). Characterisation can take place by letting the characters act and speak by themselves, or to let other characters talk to or about them, or to react towards them. See Viljoen $(2018 \mathrm{a}: 3-6)$ for a more extensive discussion of how characterisation is established in a narrative text.

2.The Gospels are read as narratives with references to their so-called narrative worlds, without invalidating their historical references. The basis of this approach is that the biblical texts are historical, as they stem from a historical context. They are primarily referential, referring to entities beyond the texts themselves, and not purely 'literary'. The narrators wrote historical narratives, addressing religious communities that were confronted with real social and historical issues (Viljoen 2018a:2). 


\section{John preparing the way for Jesus (Mt 3:1-12 // Mk 1:2-8 // Lk 3:1-19)}

Unlike Luke, Matthew does not include a narrative on John's birth and childhood. He introduces John for the first time in Matthew 3:1-12 (// Mk 1:2-8 // Lk 3:1-9), just before the start of Jesus' public ministry. The Gospel divides this in two sections. At first, John the Baptist is introduced (Mt 3:1-6), followed by his proclamation and confrontation with the Pharisees and the Sadducees (Mt 3:7-12).

Matthew pictures John the Baptist as a reliable witness to Jesus. John enters the scene with $\pi \alpha \rho \alpha \gamma i v \varepsilon \tau \alpha$ [he publicly appeared] (Mt 3:1) - a word that is repeated with the entrance of Jesus in Matthew 3:13. Except for the coming of the magi (Mt 2:1), this word is used nowhere else in this Gospel. In the Septuagint (LXX) this lexeme is usually used to signify the solemn arrival of a divine or honourable figure (e.g. Gn 35:9; Ex 19:9; Jdg 13:9; 1 Ki 13:10; 2 Ki 5:1; Es 5:5; see Davies \& Allison 2004a:321). The use of this word creates expectations and suspense around what John is about to do.

In Matthew 3:2, a summary of John's preaching is formulated: 'Repent, for the kingdom of heaven is near.' ${ }^{3}$ The core of the message is that God's reign is at hand. This statement creates expectation, which intensifies with the appearance of Jesus, the one through whom this kingdom will be established, in the subsequent scene (Mt 3:13). Later in Matthew (4:17) the same summary articulates the preaching of Jesus. This parallel signifies the gravity of John's preaching. It forms a considerable preview of Jesus' preaching to follow. The similarity between these summaries forms an inclusio of the passage in between and significantly links the ministry of John with that of Jesus (Luz 2007:134; Witherington III 2006:77).

John's ministry is defined in terms of a scriptural reference to Isaiah 40:34 (Mt 3:3). In Matthew 4:15-17, the ministry of Jesus is further defined with reference to Isaiah 9:1-2. ${ }^{5}$ This parallel between the two citations from Isaiah denotes that the initial preaching of both John and Jesus is noteworthy. These two references also carry a subordination between the two figures. Isaiah 40:3 speaks of a voice in the desert preparing the way for the Messiah, while Isaiah 9:1-2 celebrates the Messiah who has already come (Meier 1980:389). John is identified as forerunner and not the Messiah himself. He is merely preparing the way for the important one who is about to come. In the ancient Mediterranean culture, it was the custom for royal figures to have forerunners to prepare and herald their imminent arrival (Witherington III 2006:78). The scriptural reference of Matthew 3:3 explicitly

3.The First Gospel mostly speaks of $\ddot{\eta} \beta a \sigma i \lambda \varepsilon i \alpha$ tw̃v ouppavw̃v [kingdom of heaven when referring to the dominion of God. This expression forms part of Matthew's special material.

4.'A voice of one calling: "In the wilderness prepare the way for the Lord; make straight in the desert a highway for our God"' (Is 40:3).

5.'There will be no more gloom for those who were in distress. In the past he humbled the land of Zebulun and the land of Naphtali, but in the future he will honour Galilee of the nations, by the Way of the Sea, beyond the Jordan - The people walking in darkness have seen a great light; on those living in the land of deep darkness a ligh has dawned' (Is 9:1-2)

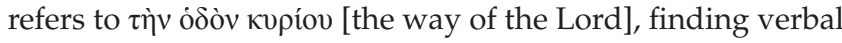
agreement with the LXX version of Isaiah 40:3. The LXX uses кupíov as translation of the Jahweh of the Hebrew version. This implies that the one to come is none other than the 'Lord' himself.

It is significant that John speaks in the wilderness, as Israel's prophets predicted a new exodus in the wilderness (Hs 2:14-15; Is 40:3). This location creates the expectation of renewal. Furthermore, John's appearance is similar to that of influential and reliable prophets of old (Mt 3:3-4). He wears a garment of camel hair and a leather belt, which pertinently reminds of Elijah's garment in 2 Kings 1:8 and has a nomadic existence in the desert. Malachi warns against the coming day of judgement and that Elijah will come to prepare the way before the Lord ( $\mathrm{Ml} \mathrm{3:1;4:5).} \mathrm{John} \mathrm{preaches} \mathrm{that}$ the Messiah is coming. He does this in a style that recalls the image of Elijah. Later in the narrative, Jesus explicitly identifies John with Elijah (Mt 11:14; 17:12). Keener (1999:116) notes that in early Judaism, there was a widespread idea that prophets in the formal sense had ceased. John's location and appearance as prophet were unusual, with the result that he drew large crowds (Mt 3:5). ${ }^{6}$

John's ministry is described as influential. People flock to him to confess their sins and be baptised (Mt 3:5-6). ${ }^{7} \mathrm{He}$ preaches remission of sins by repentance and baptism. Significantly, the First Gospel, more than the other Gospels, speaks of John as ó $\beta \alpha \pi \tau 1 \sigma \tau \grave{s}$ [the Baptist], which emphasises this practice without sacrifice in the temple in Jerusalem (Witherington III 2006:78). This most likely explains why the temple hierarchy and Pharisees were passionately opposed to his ministry.

The narrative develops around John's encounter with the Sadducees and Pharisees (Mt 3:7-12). ${ }^{8}$ John demands repentance. Matthew, like Luke, elaborates on John's preaching by reporting its focus on judgement. John even calls his audience a brood of vipers that should not expect a positive baptism (Mt 3:7). ${ }^{9}$ Jews, including the Pharisees and Sadducees, ${ }^{10}$ also need to go through the rituals of repentance and baptism, as required from proselytes (Mt 3:8). He declares that physical lineage is not enough to escape the coming wrath. John is outright in stating that God is even able to raise Abraham's children from stones (Mt 3:9). He warns

6.During evil times in Israel's history, corrupt prophets stayed in royal courts ( $1 \mathrm{~K}$ 22:6-28), while God's true messengers were forced into exile (1 Ki 17:3; 18:13).

7.John must have been an influential person as shown by Acts 18:25 and 19:1-7 where Apollos who came from Alexandria in Egypt only knew of John's baptism. In the constructed Q-material, almost a tenth of the contents is related to John and his conduct (see Witherington III 2006:111).

8.Matthew is the only evangelist that groups the Pharisees and Sadducees togethe - two groups that were hostile to each other. For Matthew, they formed a united front against Jesus and his followers.

9.Matthew's rejection of the Pharisees is particularly harsh (see Viljoen 2018b:8). The epithet 'brood of vipers' is repeated by Jesus in Matthew 12:34 and 23:33 in his woes against the scribes and pha isees). According to Keener (2002.105), to be vipers, as vipers presumably were notorious for eating their way out of the vipers, as vipers presumably were notorious for eating their way out of their
pregnant mothers' bellies.

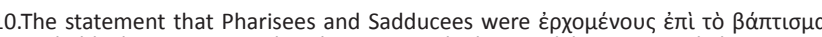
probably does not mean that they came to be baptised, but as critical observers of what was happening. The preposition éri can mean 'against'. 
TABLE 1: John ministers about Jesus.

\begin{tabular}{|c|c|c|}
\hline Mt 3:11-12 & Mk 1:7-8 & Lk 3:16-17 \\
\hline 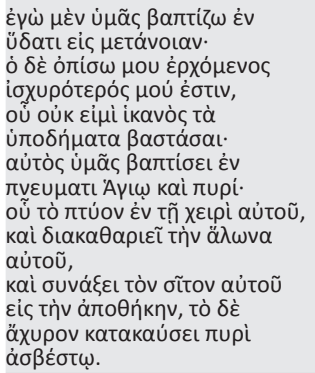 & 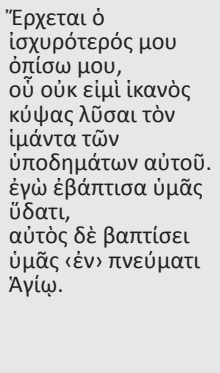 & 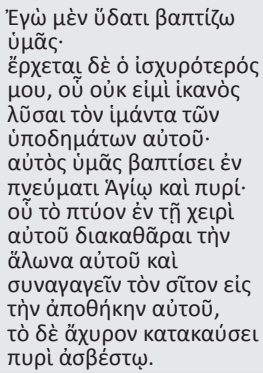 \\
\hline
\end{tabular}

them of impending judgement with the simile of the axe at the root of the trees $(\mathrm{Mt} \mathrm{3:10)}$.

Against this background, John proceeds by witnessing about the one to come. While John's ministry has been depicted as very influential, in all three Synoptic Gospels, as well as the Fourth Gospel, John the Baptist regards himself and his baptism as insignificant in comparison to that of the one to come, as demonstrated in Table 1.

In Matthew, John speaks of 'the one coming after me' (ó $\delta \grave{\varepsilon}$

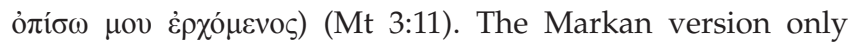
refers to 'the one after me' ( $\dot{0}$... ó $\pi i ́ \sigma \omega \mu$ ov) (Mk 1:7) and Luke states that 'the one that is more powerful than I will come'

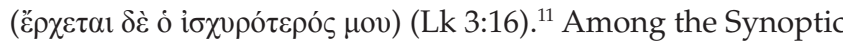
Gospels, Matthew comes the nearest to turning the reference into a title by putting it as a participle. This probably alludes to a Messianic interpretation of 'the one who comes in the name of the Lord' in Psalm 118:26. Later in the narrative, reference is made again to the one to come. In a passage relating Jesus' identity (Mt 16:13-28), he speaks of the Son of Man who will come in eschatological glory. The Son of Man, who once was rejected and despised, will come in the glory

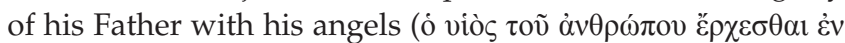

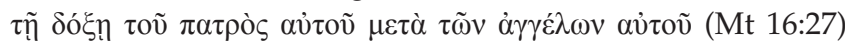
and some standing there would not taste death before they had seen the Son of Man coming (

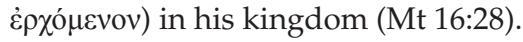

John defines the identity of the coming judge as exceptionally powerful. While Israel's prophets regarded themselves as servants of God (e.g. 2 Ki 9:7, 36; Jr 7:25), John states that he is not even worthy of being a slave of the judge. In Mediterranean culture, one of the most basic tasks of a slave was to attend to a master's feet, washing them, carrying sandals to him or her, and fastening and unfastening these (see Davies \& Allison 2004a:315; Keener 1999:130). John, however, does not even regard himself worthy of carrying (Mt 3:11) or untying (Mk 1:7 // Lk 3:16) Jesus' sandals. This statement pointedly expresses his high regard of Jesus and his own miniscule position in relation to Jesus.

In Mark, John depicts Jesus as the one to baptise with the Holy Spirit. In Matthew and Luke, John maintains the baptism with

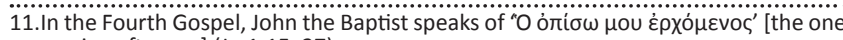
coming after me] (Jn 1:15, 27). the Spirit, but adds that he will also baptise with fire. The evangelists express John's and Jesus' baptisms in parallel. Of

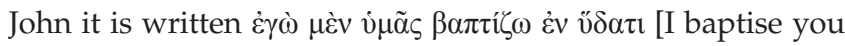

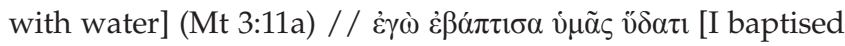

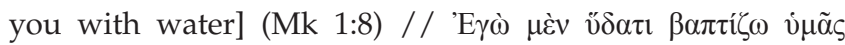

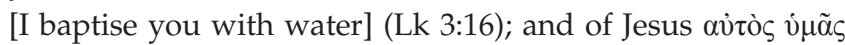

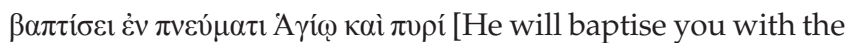

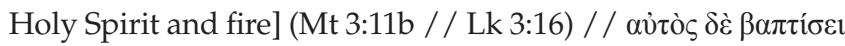

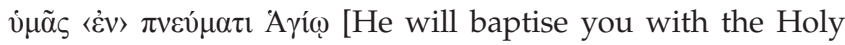

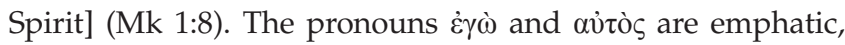
sharpening the contrast between the baptism of John and that of Jesus.

There is no predecessor of a baptiser such as Jesus. Isaiah 11:1-2; 42:1 and 61:1 describe the Davidic Messiah as one on whom the Spirit would rest, while no one but God could pour out the Spirit (Is 44:3; 59:21; Ezk 36:27; 37:14; 39:29; Jl 2:29; Zch 12:10). Similarly, no human would be able to baptise with fire. The baptism with fire probably symbolises the eschatological fire of Malachi 4:1. ${ }^{12}$ There is no human comparable to Jesus and what he is about to do.

As mentioned before, in Matthew (1:11) and Luke (3:16), John combines baptism with fire, and baptism with the Holy Spirit. The connection between fire and Spirit was common in Jewish thought (e.g. Is 32:15; 44:3; Ez 36:25-26; J1 2:28-29; see Davies \& Allison 2004a:317). An explicit link is further established between fire, Spirit and judgement in Isaiah 4:4; 30:27-28 and 4 Ezra 13:8-11. Congruent with this combination, John describes the judgement baptism in terms of harvest imagery (Mt 3:12). ${ }^{13}$ The judgement implies that some, namely the wheat will be saved, but the others, namely the chaff will be burned with unquenchable fire. The incomparable harshness of the judgement is emphasised, as chaff naturally burns out quickly, while this fire is described as unquenchable.

To synthesise: John's witness as forerunner in this scene, as a whole, reveals much about the character of Jesus. As reliable witness, John declares the importance of Jesus as the one to come. His own ministry is described as significant and in parallel to that of Jesus. Although John's ministry is very influential, it remains insignificant in comparison with that of Jesus. John regards himself unworthy to even be his slave. Jesus is much more powerful than he is. Jesus is able to baptise with the Holy Spirit and with fire - a baptism that no human being is able to perform. John depicts Jesus to be no less than the Lord himself. As Messianic figure he, and not God, will act as judge. His judgement is imminent and will be harsh, similar to the burning of chaff with unquenchable fire. His appearance instigates the coming of the kingdom of heaven.

12.'Fire' could also refer to the 'tongues of fire' with Pentecost (Ac $2: 2-4$ ), although this is less likely, as the theme of judgement is paramount in John's message.

13.John's statement in Matthew 3:10 that every tree that does not bear fruit will be chopped down and thrown in the fire, is precisely repeated by Jesus in the Sermon on the Mount (Mt 7:19). 


\section{John baptises Jesus (Mt 3:13-16 // Mk 1:9-11 // Lk 3:21-22)}

John declares that he is unworthy to serve as slave of the one to come, and he moreover regards himself unworthy to baptise Jesus.

In Matthew 3:13, Jesus becomes an active character for the first time. Matthew skilfully links the person of Jesus with John, and the baptism scene with the previous witness of

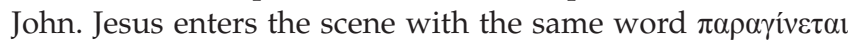
[he publicly appeared] as John in the previous scene (Mt 3:1). The parallel between these two characters is subtle; yet, the difference in their status is accentuated.

While all three the Synoptic Gospels report the baptism of Jesus, only Matthew narrates a theological dialogue between John and Jesus as shown in Table 2. John objects to baptising Jesus, and Jesus responds to this objection. In the previous pericope, John witnessed that Jesus was the mightier one and here he stresses his own inferiority again. Within the traditional Mediterranean culture of honour and shame, John's objection in the First Gospel makes perfect sense (Keener 1999:131). He objects to the reversal of proper roles:

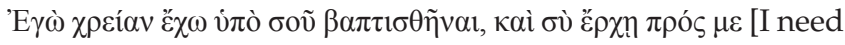
to be baptised by you, and do you come to me?]. ${ }^{14}$ Jesus was actually the one to baptise others (Mt 3:11), but he submits himself to be baptised by John. John recognises Jesus as the ultimate baptiser (Keener 1999:131). This objection demonstrates a highly developed Christology, so much so that some scholars question the historicity of these words (see Davies \& Allison 2004a:323). ${ }^{15}$ Despite John's objection, Jesus insists on being baptised. He humbles himself to be baptised by a person who is totally inferior to him. Jesus becomes the example of humility.

His response to John's objection contains the first words spoken by him in this Gospel. Jesus motivates the reason for him to be baptised, as this is required to fulfil all righteousness

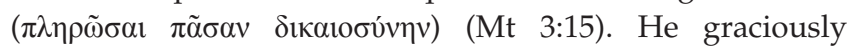
associates himself with John, as this is the right action for both to take (Meier 1980:391). Two key Matthean themes are used here, namely fulfilment (see Menken 2004) and righteousness (Davies \& Allison 2004a:325; Turner 2008:118). Matthew frequently uses the verb fulfil to introduce a citation from the Jewish Bible (Mt 1:22; 2:15, 17, 23; 4:14; 5:17; 8:17; $12: 17 ; 13: 35 ; 21: 4 ; 26: 54,56 ; 27: 9)$. This confirms that what is happening to Jesus is in accordance with God's will as declared in the Jewish Scriptures of the past. It resonates with the fact that Jesus is willing to follow the will of God in full. John no longer only testifies about the fulfiller. He now, along with the fulfiller, fulfils God's plan of salvation (Meier 1980:392; Viljoen 2007:302-305).

14.The wordplay is significant: The one to come (o épópevos - Mt 3:11) after John comes (हैpxn - Mt 3:14) to John.

15.Davies and Allison (2004a:323) regard these words as redactional to reflect a highly developed Christology of the Early Church. They furthermore argue that these words are inconsistent with John's doubt in Matthew 11:2-6. The historical quest is not dealt with in this article, as it falls outside its scope with its narrative critical approach.
TABLE 2: John baptises Jesus.

\begin{tabular}{|c|c|c|}
\hline Mt 3:13-15 & Mk 1:9 & Lk 3:21 \\
\hline 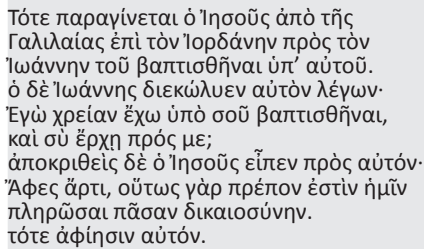 & 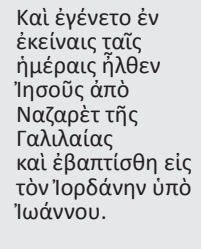 & 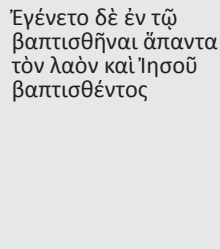 \\
\hline
\end{tabular}

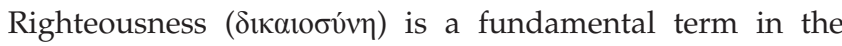
Matthean Gospel. ${ }^{16}$ It plays a significant role in how Matthew describes the function of the Law and the position of his community. ${ }^{17}$ Jesus is depicted as himself being committed to total righteousness. This correlates with Jewish expectations of the Messiah implicated in the Hebrew Bible (Jr 23:5-6; 33:15; Zch 9:9) and in Jewish writings of the period between 200 BCE and 100 CE. ${ }^{18}$ Jesus obediently fulfils all righteousness and completes Jewish Messianic hopes. The baptism of Jesus echoes the honourable act of Joseph who was a righteous man (Mt 1:19). Later in the Gospel, Jesus is again depicted as the righteous one (Mt 27:19). He fulfils all righteousness. With Jesus' determination to be baptised, he insists that he and John have to do all that God demands. ${ }^{19}$ They have to fulfil God's plans set forth for each of them in the predictions of the Jewish Scriptures (Eissfeldt 1970:213; Foster 2004:200; Loader 1997:159; Meier 1976:79). Jesus becomes the prototype of all righteousness (Luz 2007:142). He is the righteous one to fulfil the total will of God.

Jesus' baptism demonstrates his ultimate identification with Israel (Keener 1999:132). It can be regarded as his first step in bearing the sins of his people. He had to be numbered among the transgressors (Is 53:11-12). He submits himself to do God's loving will for his people. He is prepared to be their deliverer in the way that God intends (Witherington III 2006:86). As with this impending death, his baptism is vicarious.

16.The noun ठikatooúvn (righteousness) occurs seven times in the Gospel of Matthew. Matthew employs it to refer to Jesus, John the Baptist and the disciples (see Viljoen 2013a:5). In two cases, he contrasts the righteousness of the disciples with that of the Pharisees and the teachers of the Law (Viljoen 2013b:4-9).

17 Traditionally, scholars have failed to distinguish between Paul's and Matthew's

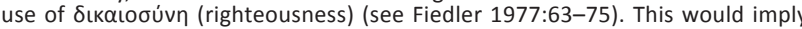
that one transposes Paul's meaning(s) of Sikalooúvn into Matthew's use of the word while denying the unique context within which Matthew employs it (Reumann 1992:737)

18.Jewish expectations of a Messiah that would act as agent of divine deliverance are frequently referred to in later Jewish writings of the period between 200 BCE and 100 CE (De Jonge 1992:777). The Psalms of Solomon, which was probably written around 50-40 BCE, anticipates a king that will free Israel from its enemies, the people of dispersion will return, and all nations will serve God. This king will serve people of dispersion will return, and all nations will serve God. This king will serve
the Lord as the ideal pious, obedient and wise man, while the unrighteousness will the Lord as the ideal pious, obedient and wise man, while the unrighteousness will the 1st century CE, speaks of a heavenly redeemer, referred to as 'the Son of man' (1 En 46:1-3), 'the Chosen One' (1 En 39:6; 40:5) and 'the Righteous One' (1 En 38:2). This redeemer is thought to have been with God from the beginning, and remains in God's presence, reveals all things to the elect and will act as judge of the world (1 En 48:3, 6). 2 Baruch, which was composed, following the destruction of the temple in $70 \mathrm{CE}$, speaks of a royal figure who will reign during a time of complete bliss where peace, joy, harmony and health will abound ( 2 Bar 71-73). In a similar vein, 4 Ezra, composed between 70 and 218 CE, speaks of an 71-73). In a similar vein, 4 Ezra, composed between 70 and $218 \mathrm{CE}$, speaks of an agent of divine deliverance. He will bring 400 years of happiness. After that period, everyone, including this agent, will die. After a period of silence as there had been at the beginning of creation, a new aeon of incorruptibility will begin with the
resurrection and judgement (4 Ez 7:26-44).

19.John came 'in the way of righteousness' (Mt 21:33) and demanded all righteousness of those who went out to be baptised by him. 
After Jesus' public act of humility, God publicly identifies Jesus as his own Son (Mt 3:16-17), echoing the words of Matthew 2:15: 'out of Egypt I called my son'. ${ }^{20}$

Jesus' interaction with John the Baptist in this scene, reveals several of his character traits. The parallel between these two characters is obvious, but so are the vast differences between them. While John is an influential and significant figure, he is considerably inferior to Jesus. Yet, Jesus humiliates himself by associating himself with John so that together they can embody God's righteousness. Jesus reverses the roles in status by insisting to be baptised by the subordinate John. While he is the fulfiller, he is therefore committed to fulfilling the total will of God. His baptism is surrogate, as he identifies with Israel. On their behalf, he is the truly righteous one.

\section{John in prison is uncertain about Jesus (Mt 11:2-19 // Lk 7:18-35)}

The narrative in Matthew 11-12, leading up to the Jesus' parable-discourse in Matthew 13, involves a variety of interactions between Jesus and John's disciples, the Pharisees and his own family. The common thread in these interactions is that Jesus is misunderstood by them, even by those who are supposed to know and support him (Witherington III 2006:229). Even John, the one who prepared his coming, is in doubt about Jesus' conduct.

As indicated in Table 3, Luke shares Matthew's narrative around John's doubt while in prison - an episode that does not occur in Mark. Whereas John previously passionately proclaimed Jesus' identity (Mt 3:14), he has become discouraged and has begun to doubt. Although this seems contradictory to his courageous proclamation earlier in the narrative, such reaction has several antecedents in Jewish Scriptures (Keener 1999:334). After Elijah had fearlessly challenged the Baal prophets on Mount Carmel, he later became disappointed and asked the Lord to take his life (1 Ki 19:4). When David was pursued by Saul, he became so disappointed and frustrated that he almost succumbed, had it not been for Abigail's intervention (1 Sm 25:21-35). Jeremiah, who courageously prophesied against his people, later cursed the day of his birth (Jr 20:14-18). Like these prominent figures in Jewish history, John is also depicted as a frail person with weaknesses. ${ }^{21}$ Jesus, nevertheless, describes him as a reliable character.

Matthew 11:2-19 can be broken down to three parts: verses 2-6, 7-15 and 16-19. Each of these parts has to do with John the Baptist and each is introduced by a question.

The first part narrates Jesus' interaction with John's disciples.

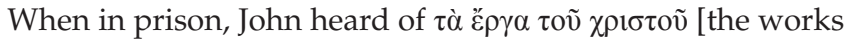

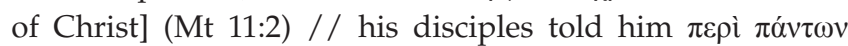

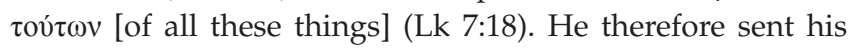
20.See Viljoen (2019:1-7) for the characterisation of Jesus by God the Father.

21.Limited weaknesses of reliable characters make them figures with whom readers can identify (Keener 1999:335)
TABLE 3: John in doubt.

\begin{tabular}{|c|c|}
\hline Mt 11:2-3 & Lk 7:18-19 \\
\hline 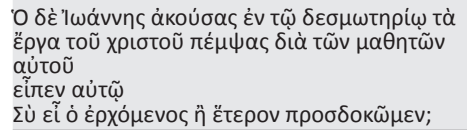 & 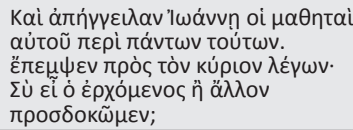 \\
\hline
\end{tabular}

disciples to ask him (Mt 11:3) / / the Lord (Lk 7:19) whether

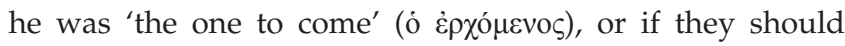

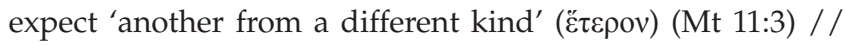

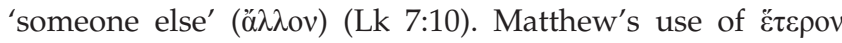
emphasises the contrast between what John expects and what he then hears of Jesus. John does not ask this despite what he has heard of Jesus, but based on what he has heard. Matthew explicitly mentions that John has heard of the deeds of the Messiah. John is uncertain whether they should look elsewhere for 'the one to come'. What he has heard of Jesus, does not fit his expectation of 'the one to come'. He expects the Messiah to carry out judgement as he has proclaimed (Mt 3:1-12), but instead Jesus helps and heals people. John's expectations of the Messiah are therefore incomplete even though they are correct (Keener 1999:335).

John's question and Jesus' response to it represent significant traits of Jesus' character. John envisages the future role of Jesus as 'the one who would come after him' (ó $\delta \dot{\varepsilon}$ ó $\pi$ í $\sigma \omega$

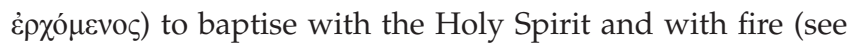
Mt 3:11); yet, he does not realise that Jesus still has the task of saving his people before returning as judge.

In response to John's question, Jesus alludes to passages from Isaiah which mention similar miracles as those he is performing (Is 26:19; 29:18-19;35:5-6;61:1), ${ }^{22}$ but significantly omits those parts of the passages that refer to judgement (e.g. Is 29:20; 35:4; 61:2; see Mt 11:4-6). His response consists of six short clauses with a closing beatitude. In his ministry up to the stage that John envisages, Jesus fulfilled the Old Testament hopes of healing. He brought about eschatological healing. Although these signs were less spectacular than the baptism with fire, they already offered indications of the Messianic era.

At that stage, Jesus had not yet baptised with the Holy Spirit and with fire as John had expected, but what Jesus had done, already demonstrated that he was endowed by the Spirit. However, the final beatitude (Mt 11:6) suggests that whoever stumbles and takes offence at Jesus would eventually experience eschatological judgement (Witherington III 2006:231). The beatitude can be interpreted as a subtle warning to John not to be led to disbelief and to take offence at him ( $\mu$ خे $\sigma \kappa \alpha v \delta \alpha \lambda \imath \sigma \theta \tilde{\eta} \dot{\varepsilon} v \dot{\varepsilon} \mu o i ́)$ if he was not the type of Messiah John expected. In effect, this amounts to a vital recognition: blessed is the one that does not look for another kind of Messiah, for Jesus is the kind of Messiah that God wills.

Once John's disciples leave, Jesus positively testifies about John to the crowds (Mt 11:7-15). That is, if Jesus is the coming

22.There is no mention of the lepers in Isaiah, which could imply that Jesus' healing goes even beyond Old Testament expectations. 
one, who is John in relation to him? Jesus uses a series of rhetorical questions, each time excluding certain possibilities, to leave the hearers with one possibility only. John is none other than Elijah who was to come, the promised forerunner of the Messiah. John is not a weakling, easily influenced like a reed swayed by the wind (Mt 11:7). He is no pampered court prophet who, for his own benefit, would prophesy to meet the favour of royalty (Mt 11:8). ${ }^{23}$ On the contrary, he was imprisoned, because he had the courage to criticise Herod's marriage (Mt 14:3-4). Jesus cites Malachi 3:1 (probably conflated with Ex 23:30) to describe John's ministry (Mt 11:10). He is the greatest figure in history so far (Mt 11:11). ${ }^{24}$ Jesus identifies him with Elijah (Mt 11:14). In Jewish tradition, Elijah is regarded as the one who has come to prepare the way for God and not only of the Messiah. This signifies Jesus' divine status (Keener 1999:338). John's greatness implies the greatness of Jesus for whom he comes to prepare the way. John's role is great because of the greatness of the one he has come to introduce.

Once the reader has been confronted with the truth about Jesus (Mt 11:2-6) and John (Mt 11:7-15), a report follows of how contemporaries respond to both (Mt 11:16-19). Instead of repenting or rejoicing, this generation rejects God's messengers. 'This generation' ( $\gamma \varepsilon v \varepsilon \alpha$ ) $)$ is a technical term with its roots in the Old Testament where the generation in the wilderness is called 'faithless', 'evil', 'sinful', 'perverse' and 'crooked' (Dt 1:35; 32:5, 20). The term does not firstly refer to a chronological duration, but to bad characters ${ }^{25}$ (Davies \& Allison 2004b:260). These bad characters are viewed as akin to spoiled and finicky children who are never satisfied. Once again the parallel between John and Jesus is notable: 'John

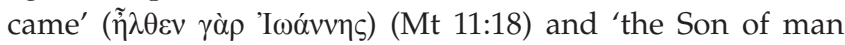

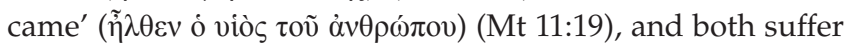
rejection (Meier 1980:398). ${ }^{26}$ John would in fact soon face execution (Mt 14:3-12) and Jesus would likewise be executed on the cross (Mt 27:32-56). Jesus rebukes 'this generation' that criticises his and John's ministries even if they stand in contrast to each other. Jesus concludes with a statement that, despite this poor reaction of the people, God's wisdom will be vindicated by his and John's actions (Mt 11:19). Their ministries manifest the works of divine wisdom.

This interaction between Jesus and John, even as it occurs in terms of John's disciples, sheds further light on Jesus' character. His people misunderstand him, even the one who

23.Jesus' recommendation of John has more to it than what immediately meets the eye. It seems that Jesus is contrasting John with Herod Antipas. Herod Antipas was
known for wearing royal apparel. It seems that Jesus critiques him as a reed known for wearing royal apparel. It seems that Jesus critiques him as a reed
blowing in the wind, swaying in whichever direction political winds blow. It is also blowing in the wind, swaying in whichever direction political winds blow. It is also
noteworthy that Herod used a reed as an emblem on his coins before 26 CE. Jesus
probably reflects on this emblem in his remark (Witherington III 2006:232).

24.Jesus' statement in Matthew 11:11 is puzzling. He begins by saying that no one born thus far is greater than John, but then proceeds by saying that the least in the kingdom of heaven is greater than him.

25.These bad characters the Matthean Jesus refers to are probably the elite and leaders of the Jews.

26.The presence of the lexeme $\tilde{\eta} \lambda \theta \varepsilon v$, has led some scholars to argue that this saying belongs to logia and Reflexionszitate. On form-critical grounds, Von Harnack (1912:1-30) identified such a Gattung in the synoptic tradition with 'die ausdrücklichen Selbstzeugnisse Jesu über den Zweck seiner Sendung und seines ausdrücklichen Selbstzeugnisse Jesu über den Zweck seiner Sendung und seines
Kommes'. With the 'has come'-statements, Jesus was conscious of his divine Kommes'. With the 'has come'
mission (Guelich 1982:134-135). is supposed to be his ultimate supporter. He is not the type of Messiah that John and 'this generation' expect, but the type God wants. He has not yet executed judgement. He miraculously heals people with all kinds of ailments. However, the parallel between John and Jesus is significant. John comes and the Son of Man comes, and both are disregarded and rejected by their people. Both would be executed. Nevertheless, God's wisdom would be vindicated through him and John. His and John's actions speak of divine wisdom.

\section{Herod confuses Jesus with the beheaded John (Mt 14:1-12 // Mk 6:14-19 // Lk 3:19-20 and 9:7-9)}

All three Synoptic Gospels narrate John's beheading (Mt 14:1-12 / / Mk 6:14-19 / / Lk 3:19-20 and 9:7-9). ${ }^{27}$ While the Gospels generally focus on Jesus, this episode focusses on John. However, this episode indirectly refers to Jesus, as Herod the tetrarch confuses Jesus with the beheaded John, as shown in Table 4.

The scene opens with Herod's reaction to what he has heard of Jesus (Mt 14:1-2 / / Mk 6:14-16 / / Lk 9:7-9), followed by a flashback to the beheading of John the Baptist (Mt 14:3-11 // Mk 6:17-28 // Lk 3:19-20). The concluding remark on John's burial (Mt 14:12 // Mk 6:29), reintroduces the flashback into the main thread of the narrative.

In all three Synoptic Gospels, Herod's reaction to Jesus shows that a bad conscience bothers him. Matthew significantly shortens Mark's version of Herod's reaction, mentioning only Herod's words, although the catchphrase the powers

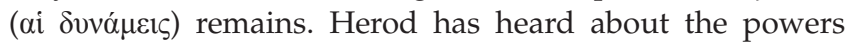
working in Jesus (Mt 14:22 // Mk 6:14). Luke speaks of the

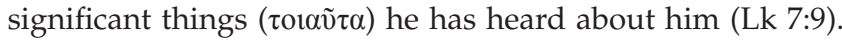
This narrative depicts Jesus as one performing powerful deeds. John must have been an influential person and therefore Jesus is also that, but so much more.

This narrative informs the macro text of the First Gospel. Matthew 13:53-58 describes Jesus' rejection in Nazareth. He is a 'prophet without honour' among his people. His forerunner is met with a similar fate. ${ }^{28}$

The parallel between the missions of Jesus and John has built up to this point of culmination (Keener 1999:387). John introduces Jesus and proclaims the same message that Jesus would (Mt 3:2 and 4:17). Jesus warns his followers of persecution and what it implies to be a righteous prophet $(\mathrm{Mt}$ 10:17-42) and then proceeds by praising John as his ally (Mt 11:2-19). This is followed by narratives about those who reject Jesus (Mt 11:2-25 and 12:1-14). John's fate as forerunner of Jesus reaches its climax in Matthew 14:1-12. This narrative of John's beheading provides a signal of what lies ahead for 27.John 3:24 only mentions that John was put in prison.

28.The motif of foreshadowing is common to ancient Mediterranean literature, for instance in the Odyssea of Homer where Agamemnon's death serves as warning that Odysseus could face the same fate (Hom. Od 13.383-385). 
TABLE 4: Herod confuses Jesus with the beheaded John.

\begin{tabular}{|c|c|c|}
\hline Matthew 14:1-2 & Mark 6:14-16 & Luke 9:7-9 \\
\hline 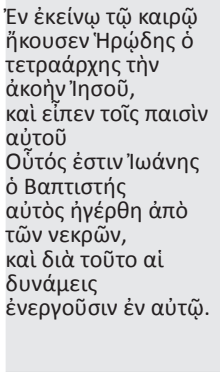 & 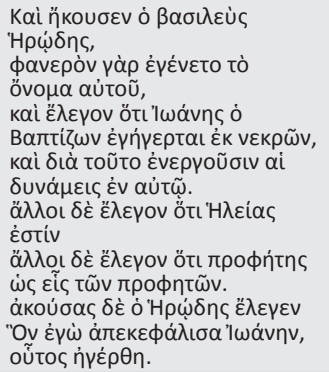 & 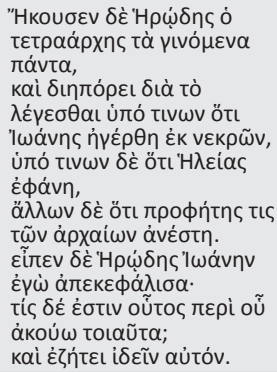 \\
\hline
\end{tabular}

Jesus himself (Keener 1999:402; Luz 2001:307; Witherington III 2006:281). On the Mount of Transfiguration, Jesus explicitly mentions how the brutal killing of John (as Elijah who has come) precedes his own suffering and death (see Mt 17:12). The evangelist prepares his readers for the violent end that Jesus is also about to meet. ${ }^{29}$

Herod Antipas acts as forerunner to the Jewish leaders and crowds during the crucifixion of Jesus. Just as Herod initially hesitates to execute John but later concedes, so would Pontius Pilate also hesitate but later grant the wish of the Jewish leaders and crowds to have Jesus crucified. ${ }^{30}$ The first readers of Matthew would have thought of the disobedience of Israel that had often led to the persecution and killing of their prophets (Luz 2001:307). The picture of John as one who criticised Herod for his improper marriage, fits the character of Elijah whose message was also rejected $(1 \mathrm{Ki}$ 19:1-2; see Witherington III 2006:282).

In Matthew 11:4, John's disciples return to him with a message from Jesus. Now in Matthew 14:12, they return from John with a message to Jesus. With nowhere else to go, John's disciples go to Jesus as the one John had witnessed about. Once Jesus hears of what happened to John, he withdraws to a private place (Mt 14:13), for with John dead, he is the next in line to be martyred. When John's disciples announce the Baptist's death, they implicitly also announce Jesus' impeding death (Meier 1980:400).

The recurrent theme around both John and Jesus is the violent fate of righteous prophets at the hands of the evil leaders of Israel - similar to what happened in Elijah's case. The narrative later notes that the crowds considered John (Mt 21:26) and Jesus to be prophets (Mt 21:11, 46).

The scene therefore again demonstrates that Jesus and John belong together. John makes a huge impact and Jesus, with his powerful deeds, even more so. Both proclaim the same message, are confronted by the same opponents, and suffer a similar fate. However, there is subordination. John prepares the way for Jesus. He does this with his proclamation, but also with his martyrdom and death.

29.Besides the martyrdom of John and Jesus, Jesus also predicts that those who follow him would be persecuted (Mt 5:12; 17:12)

30.See Viljoen (2011:336-342) on the irony with the positions of Herod Antipas and Pilate. Although they are in powerful positions, they turn out to be pathetic figures, not being able to do what is right due to their audiences.
TABLE 5: Some say Jesus is John the Baptist.

\begin{tabular}{|c|c|c|}
\hline Mt 16:14 & Mk 8:28 & Lk 9:19 \\
\hline 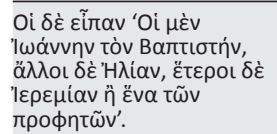 & 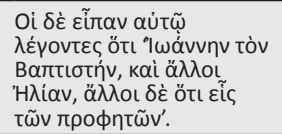 & 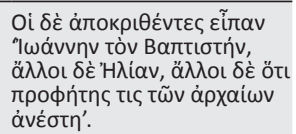 \\
\hline
\end{tabular}

\section{Some say Jesus is John the Baptist (Mt 16:14 // Mk 8:28 // Lk 9:19)}

Israel's rejection of Jesus (Mt 13:53-58; 16:1-12) precedes the climax of the identification of Jesus in Matthew as the Christ and Son of the living God (Mt 16:16). Jesus asks his disciples: 'Who do the people say the Son of Man is?' (Mt 16:13) // 'Who do the people say I am?' (Mk 8:27) // 'Who do the crowds say I am?' (Lk 9:18). Based on their answers, it seems that it is not only Herod Antipas who thinks Jesus is John (Mt 14:2 / / Mk 6:14 // Lk 9:7), as Table 5 indicates.

In the ancient Mediterranean culture, names were considered to be clues to one's character (Witherington III 2006:309). A person's name indicated what people thought of that person. Mark and Luke record three popular opinions about who people thought Jesus was. Some regarded him as John the Baptist, others as Elijah and still others as one of the prophets. Matthew adds a fourth possibility, that of Jeremiah. ${ }^{31}$ The common denominator is that people saw Jesus as some kind of prophet. In their thought, they apparently entertained specific categories of people and all these fell into the category of a prophet. When Jesus spoke of John the Baptist, he himself referred to expectations of truthful prophets (Mt 11:9). They do not enjoy luxury in kings' courts as those who prophesy in such a way as to please the rulers while being influenced by the blowing of political winds. They rather suffer resistance for being prepared to proclaim even what the rulers did not welcome.

John was such as a prophet (Mt 11:9). His apparel, diet and message gave witness to this. He was even identified with Elijah who has returned. Many Jews expected the return of Elijah or one of the other influential prophets. Matthew adds a reference to Jeremiah. An expectation probably existed among Jews of an eschatological return of Jeremiah (Luz 2001:361). It seems that the people noticed some kind of parallel between Jeremiah, John and Jesus. All of them were prophets of judgement, spoke against the temple, suffered persecution, and were imprisoned. Furthermore, both Jeremiah and Jesus were associated with Moses (Jr 1:4-12 with Ex 3:7-4:17 and Dt 18:18; see Davies \& Allison 2004b:618). The ancient apocryphal document from the 1st century CE, 'Lives of the Prophets', provides an account of the lives of 23 of the Old Testament prophets. With regard to Jeremiah, this document reads: 'And God bestowed his favour upon Jeremiah ... so that he might become a partner of Moses' (Liv. Proph. Jr 19:1).

31.It seems that Matthew had a special interest in Jeremiah (Davies \& Allison 2004b:619). He explicitly quotes Jeremiah in Matthew 2:17 and 27:9. The words of the Matthean Jesus in many instances echo sayings from Jeremiah (Mt 7:22 echoes the Matthean Jesus in many instances echo sayings from Jeremiah (Mt 7:22 echoes
Jr 14:14 and 29:13-14; Mt 11:29 the words of Jr 6:16; Mt 21:13 the words of Jr 14:14 and 29:13-14; Mt 11:29 the words of Jr 6:16; Mt 21:13 the
Jr 7:11; Mt 23:34 the words of Jr 7:25-26; Mt 26:28 that of Jr 31:31-34). 
Due to the nature of Jesus' message and activities, he seemingly fitted into the category of these influential prophets who were met with resistance (see Mt 21:11, 46). His miracles and preaching of repentance reminded the Jews of John, Elijah, Jeremiah and other prominent prophets.

It is noteworthy that others, and not only the disciples, did not recognise him as the Messiah. When Simon Peter as spokesperson confessed Jesus to be the Christ, the Son of

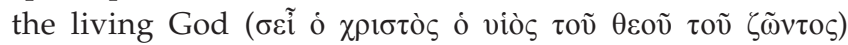
(Mt 16:16), Jesus stated that this recognition did not result from human logic. He would not have come around to the right answer about Jesus' identity on his own account: 'Blessed are you, Simon son of Jonah, for this was not revealed to you by flesh and blood, but by my Father in heaven' (Mt 16:17).

The fact that the people associated Jesus with John, or one of the other prophets, further reveals some of Jesus' character traits. His message and activities were highly significant and typical of these prominent prophetic figures. He did not enjoy luxury. He was met with resistance as he did not prophesy what the rulers and nation wanted to hear. Furthermore, this scene narrates that true understanding of the identity of Jesus cannot emanate from human logic, but has to be revealed to humans by God the Father.

\section{Jesus states that John is Elijah who had to come (Mt 17:1-13 // Mk 9:2-13 // Lk 9:28-36)}

Jesus' transfiguration on a mountain ${ }^{32}$ provides a proleptic foretaste of his glory when he will return. ${ }^{33}$ This prolepsis is simultaneously analeptic referring back to Moses and Elijah. All three Synoptic Gospels narrate this transfiguration along with the appearance of Moses and Elijah (Mt 17:1-13 // Mk 9:2-13 / / Lk 9:28-36). Moses and Elijah were considered the two great prophetic figures of the Old Testament. The transfiguration scene reflects the typology of Moses on Mount Sinai when Jesus goes up the mountain and comes down again (Ex 24:12, 15-18; 34:3), the six days (Ex 24:16), the select group (Ex 24:1), the shining face/skin (Ex 34:29-35), a bright cloud (Ex 24:15-18; 34:5), a voice from heaven (Ex 24:16) and the fear of the bystanders (Ex 34:29-30). Elijah is also known for his experience on Mount Horeb (1 Ki 19), which is generally considered to be the same as Sinai. After the departure of Moses and Elijah, a voice from heaven instructs the disciples to listen to Jesus rather than Moses and Elijah. Jesus is therefore portrayed as incomparably greater than Moses and Elijah (Luz 2001:398).

The disciples' expectation of the eschaton has been confused by this transfiguration event: 'Why then do the teachers of

32.The narrative does not mention the name of the mountain on which the transfiguration took place. Traditionally, it was thought that it took place on Mount transfiguration took place. Traditionally, it was thought that it took place on Mount Hermon.

33.The description of the bright cloud that overshadowed them is reminiscent of God's Shekinah in the tabernacle (Ex 40:34-38). the law say that Elijah must come first?' (Mt 17:10). ${ }^{34}$ In response Jesus confirms that Elijah has already come, although the people did not recognise him. Jesus referred to John the Baptist. The disciples should have known this already, as Jesus earlier identified John with Elijah (Mt 11:10, 14). As the Jewish opponents do not recognise John as Elijah, they do not allow him to fulfil his mission as forerunner to prepare for the coming of the Messiah. Instead, they kill him ${ }^{35}$ (Mt 17:11). The Son of Man is destined to suffer rejection from the same people (Mt 17:12). ${ }^{36}$ The Son of God is the type of Messiah whose glory the disciples sensed on the Mount of Transfiguration (Mt 17:1-8), but who would also suffer deep humiliation and rejection (Mt 17:9-13).

Matthew's editorial remark (Mt 17:13) draws the scene to a close. Although it is implied in Mark's version, Matthew's remark is unique, because it mentions that the disciples then

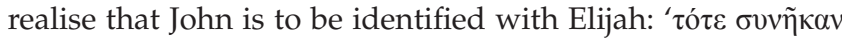

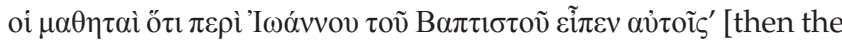
disciples understood that he spoke to them about John the Baptist]. This is the second time that Matthew makes this equation explicit, having done so already in Matthew 11:14.

This scene, too, reveals character traits of Jesus. The evangelist once again draws a parallel between John and Jesus, and once again John is subordinate to Jesus. Whereas the disciples have to listen to Moses and Elijah, and to John due to his identification with Elijah, they now have to listen to Jesus. John acts as forerunner to the Messiah. Jesus is the expected Messiah. Even though Jesus is the exalted one, he is determined to be rejected and enter martyrdom. Similar to Elijah and John, he will also be rejected and like John eventually killed. However, he has the ultimate authority to speak as prophet and lawgiver. Jesus' final words in Matthew confirm this: 'All authority in heaven and on earth has been given to me ... teach them to obey everything I have commanded you' (Mt 28:18-20). By humiliating himself, he brings restoration for his people.

\section{The Jewish leaders reject John and Jesus (Mt 21:23-32 // Mk 11:27-33 // Lk 20:1-8)}

When Jesus enters the temple courts, and while he is teaching, he is challenged by the chief priests and the elders of the

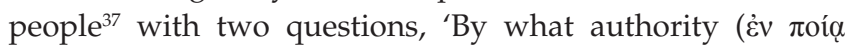

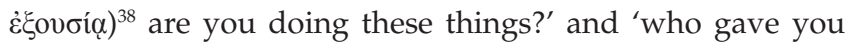

34.This is a probable reference to Malaquias 4:5-6: 'See, I will send the prophet Elijah to you before that great and dreadful day of the Lord comes. He will turn the hearts of the parents to their children, and the hearts of the children to their parents; or else I will come and strike the land with total destruction.' Rabbinic writings also link Elijah with the Messiah's coming, for example b. 'Erubin43b, b. Baba Mesia'a $85 \mathrm{~b}$ and Pesiqta Rabbati 35:4.

35.Strictly speaking, it was not the scribes who killed John, but they form part of the common Jewish opponents.

36.Jesus' rejection carries a strong allusion to Isaiah 53.

37.These two groups would also play a prominent role in accusing Jesus on the Thursday before his crucifixion (Mt 26:3, 47; $27: 1,3,12,20$ ). The playing out of this scene predicts what was going to happen in the passion narrative.

38.Authority ( $\dot{\varepsilon} \xi o u \sigma i \alpha$ ) forms a catchword, as it appears four times in this short narrative (Mt 21:21, 23-24, 27). 


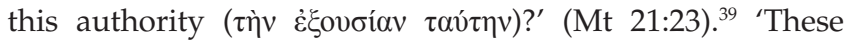
things' probably do not only refer to Jesus' teaching at that stage, but also his preceding actions described in Matthew 21. Subsequently, they challenge his authority to act and teach as the Messianic king (Davies \& Allison 2004c:159). The Jewish leaders, who assume to act with God-sent authority, question the source of Jesus' authority. In Matthew 9:3 some teachers of the law accused him of blaspheming with the implication that they now again could suspect some evil supernatural source behind Jesus' teaching and conduct (Witherington III 2006:399).

In his response, Jesus does not explicitly claim his Messianic authority. However, like the two questions of the Jewish leaders, he responds with a double counter-question

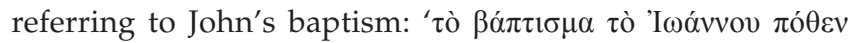

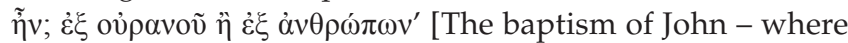
did it come from? From heaven, or from men?] (Mt 21:25 / / Mk 11:30 / / Lk 20:3). ${ }^{40}$ The question is no longer what Jesus thinks, but what the Jewish leaders think. Jesus makes use of synecdoche when he speaks of John's baptism, as he actually refers to John's entire prophetic ministry. Implicitly, Jesus compares John's prophetic authority with his own. The question whether John was a true prophet is directly related to the question of Jesus' authority. John testified to Jesus (Mt 3:14); if one thus accepts John's ministry, one should also accept Jesus' authority.

The Jewish leaders sit with a dilemma. Due to the crowds' estimation of John, they cannot deny John's authority, but by acknowledging his authority, they also have to acknowledge Jesus' authority. They therefore decide to feign ignorance (Mt 21:26) and respond: 'We don't know' (Mt 21:27). Their response reveals their undecidedness and incompetence and thereby, ironically, exposing their own lack of authority. Nevertheless, their response hints to the parallel fate of Jesus and John, as both are rejected and executed. This sad rejection, as spoken of in Matthew 17:12, now becomes a reality. The passion narrative that follows, depicts the struggle between good and evil.

Jesus ends the dispute by matching the refusal of the Jewish leaders with his own refusal. His closing words, 'Neither

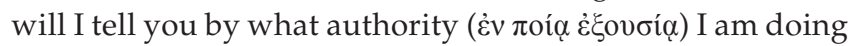
these things' (Mt 21:27), match the Jewish leaders' opening challenge of his authority (Mt 21:23) to form an inclusio with the catchword 'authority'. Jesus' authority is not put in doubt, but actually confirmed by the outcome of this dispute. $^{41}$

The next pericope in Matthew contains Jesus' parable of the two children (Mt 21:28-31) - a parable which is only

39.This challenge of Jesus' authority recalls the authority of Jesus' teaching in the Sermon on the Mount where it is stated that Jesus teaches with authority and not like that of the teachers of the law (Mt 7:28-29).

40.Matthew turns the one question of Mark into two to match the two questions of his opponents.

41.The irony of this ending borders on satire, which is similar to what is found in Greco-Roman controversy narratives where opponents had no answer to the pun of the wise character (Keener 1999:506) found in this Gospel. It effectively concludes the preceding controversial dialogue about John's and Jesus' authority. This parable is the first of three parables that are highly critical of the Jewish leadership (Keener 1999:507). In it, the first child represents the humble who regard John and Jesus with humility, while the second child represents the Jewish leaders who fail to accept John's ministry despite their religious profession. The normal rule in parables that contrast characters in this way is that emphasis goes to the last character (Luz 2005:25). In this case, the emphasis falls on those presented by the second child. In conclusion to this parable, Jesus remarks that John comes to them in the way of

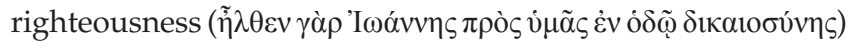
(Mt 21:32). With these words, Jesus affirms John's authority which recalls Matthew 21:25 where he asks the Jewish leaders about it. The metaphor reading 'the way of righteousness' originates from the Hebrew Bible and refers to the notion of living according to God's just will (Hagner 1995:614; Przybylski 1980:94-96; Strecker 1971:187; Turner 2008:509; Viljoen 2013b:6-7). It includes the full spectrum of a proper response to God, including repentance and good deeds (Senior 1998:238). It clearly refers to righteous conduct. ${ }^{42}$ John preaches and exemplifies righteousness (France 2008:310). He ministers with authority; however, the Jewish leaders refuse to listen to him. Their conduct reveals the hypocrisy of their claim to be righteous spiritual leaders.

Matthew 21:23-32 once again articulates the parallel between Jesus and John. The controversy dialogue and subsequent parable focus on John's and Jesus' authority. They derive their authority not from men or any other evil supernatural force, but from God. John testified with authority to Jesus which confirms his God-given authority as Messianic king. While both are fully committed to God's righteousness, they are rejected and executed by unresponsive leaders of Israel.

\section{Conclusion}

Matthew depicts John the Baptist as an influential and reliable character to give witness to Jesus. His appearance and conduct are similar to that of the influential and reliable prophets of old. His ministry draws numerous crowds who respect him. John preaches and exemplifies righteousness. He ministers with authority; however, the Jewish leaders refuse to listen to him. He is a frail person with weaknesses who becomes confused and disappointed. Jesus, nevertheless, describes him as a reliable person. John is not a weakling, easily influenced like a reed swayed by the wind or a pampered court prophet who, for his own benefit, would prophesy to meet the favour of royalty.

Although John's ministry is influential, it is insignificant in comparison with that of Jesus. The difference between John's and Jesus' status is continually accentuated. John regards himself unworthy even to be Jesus' slave. Jesus is much greater and more powerful than he.

42.This reference to John's righteousness (8ckaloouvv) recalls Jesus' insistence to be baptised by John to fulfil all righteousness (Mt 3:15) 
John witnesses to Jesus as the one to come, the Messiah. He depicts Jesus to be no less than the Lord himself. He is exceptionally powerful. With his coming, he will instigate the coming of the kingdom of heaven. He will act as judge, and his judgement is imminent and will be harsh. He is committed to fulfil all righteousness. His actions speak of divine wisdom and God's wisdom will be vindicated through him. He has God-given authority.

Matthew 3 forms part of the setting of the stage for Matthew's plot. In this exposition, the character of Jesus is introduced as the protagonist, and John the Baptist acts as his supporter by announcing his mission. Simultaneously, the antagonists are identified. Once this stage is set, conflict rises and in Matthew 11, both Jesus and John is rejected. In approach to the climax, John is beheaded (Mt 14), which hints towards a similar fate that would await Jesus. Scenes follow in which the status of John as credible forerunner is questioned by the antagonists, yet confirmed by Jesus (Mt 16 and 17). This leads up the climax where both John and Jesus are rejected (Mt 21). Despite this rejection, God's wisdom is vindicated when the plot unravels as Jesus eventually conquers death and declares his authority.

In the time of the New Testament, multiple Jewish expectations of a royal or divine Messianic figure did exist. However, the Matthean narrator argues that Jesus surpasses these expectations - even those of John the Baptist. Jesus embodies the type of Messiah that God wants. According to God's will, he has not executed judgement as yet. He miraculously heals people with all kinds of ailments, even more so than the salvific Messianic figure depicted in Jewish Messianic texts. He identifies himself with Israel and becomes the example of humility. He is met with resistance. While he is the exalted one, he is determined to enter rejection and martyrdom. Similar to John and faithful prophets of old, a faithless Jewish leadership and the manipulated Jerusalem crowds also reject him. By humiliating himself, he brings restoration for his people.

\section{Acknowledgements Competing interests}

The author declares that he has no financial or personal relationships which may have inappropriately influenced him in writing this article.

\section{Author's contributions}

I declare that I am the sole author of this research article.

\section{Ethical consideration}

This article followed all ethical standards for carrying out research without direct contact with human or animal subjects.

\section{Funding information}

This research received no specific grant from any funding agency in the public, commercial, or-not-for-profit sectors

\section{Data availability statement}

The authors confirm that the data supporting the findings of this study are available within the article.

\section{Disclaimer}

The views and opinions expressed in this article are those of the author and do not necessarily reflect the official policy or position of any affiliated agency of the author.

\section{References}

Anderson, J.C., 1994, Matthew's narrative web; over and over again, Sheffield Academic Press, Sheffield.

Davies, W.D. \& Allison, D.C., 2004a, A critical and exegetical commentary on the gospe according to Saint Matthew: Matthew 1-7, vol. 1, T\&T Clark, London.

Davies, W.D. \& Allison, D.C., 2004b, A critical and exegetical commentary on the gospel according to Saint Matthew: Matthew 8-18, vol. 2, T\&T Clark, London.

Davies, W.D. \& Allison, D.C., 2004c, A critical and exegetical commentary on the gospel according to Saint Matthew: Matthew 9-28, vol. 3, T\&T Clark, London.

De Jonge, M., 1992, 'Messiah', in D.L. Freedman (ed.), The Anchor Bible Dictionary, vol. 4, pp. 777-788, Doubleday, New York, NY.

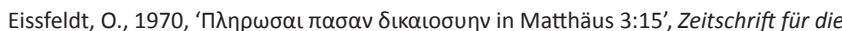
neutestamentliche Wissenschaft 61(3 \& 4), 209-215. https://doi.org/10.1515/ zntw.1970.61.3-4.209

Fiedler, M.J., 1977, 'Gerechtigkeit im Matthäus-Evangelium', Theologische Versuche 8, 63-75.

Foster, P., 2004, Community, law and mission in Matthew's gospel, Mohr Siebeck, Tübingen. (WUNT, 2, Reihe 177).

France, R.T., 2008, Matthew. An introduction and commentary, vol. 1, InterVarsity Press, Nottingham. (Tyndale New Testament commentaries).

Guelich, R.A., 1982, The Sermon on the Mount: A foundation for understanding, Word, Waco, TX.

Hagner, D.A., 1995, Word biblical commentary: Matthew 14-28, Word Books, Dallas, TX.

Keener, G.S., 1999, A commentary on the Gospel of Matthew, Eerdmans, Grand Rapids, MI.

Keener, G.S., 2002, The IVP Bible Background Commentary; New Testament, IVP Academic, Downers Grove, IL.

Kingsbury, J.D., 1986, Matthew as story, Fortress Press, Philadelphia, PA.

Loader, W.R.G., 1997, Jesus' attitude towards the Law. A study of the gospels, Mohr Siebeck, Tübingen. (Wissenschaftliche Untersuchungen zum Neuen Testament 2 : Reihe).

Luz, U., 2001, Matthew 8-20, Fortress Press, Minneapolis, MN.

Luz, U., 2005, Matthew 21-28, Fortress Press, Minneapolis, MN.

Luz, U., 2007, Matthew 1-7, Fortress Press, Minneapolis, MN.

Meier, J.P., 1976, Law and history in Matthew's gospel, Biblical Institute Press, Rome.

Meier, J.P., 1980, 'John the Baptist in Matthew's Gospel', Journal of Biblical Literature 99(5), 383-405. https://doi.org/10.2307/3265373

Menken, M.J.J., 2004, Matthew's Bible: The Old Testament text of the evangelist, Leuven University Press, Leuven.

Powell, M.A., 1990, What is narrative criticism?, Fortress Press, Minneapolis, MN.

Powell, M.A., 2009, 'Literary approaches and the Gospel of Matthew', in M.A. Powell (ed.). Methods for Matthew, pp. 44-82, Cambridge University Press, Cambridge.

Przybylski, B., 1980, Righteousness in Matthew and his world of thought, Cambridge University Press, Cambridge. (Monograph series).

Reumann, J., 1992, 'Righteousness, early Judaism', in D.L. Freedman (ed.), The Anchor Bible Dictionary, vol. 5, pp. 736-742, Doubleday, New York, NY.

Senior, D., 1998, Matthew, Abington Press, Nashville, TN. (Abington New Testament Commentaries).

Strecker, G., 1971, Der Weg der Gerechtigkeit: Untersuchung zur de Matthäus, Vandenhoeck \& Ruprecht, Göttingen.

Tolmie, D.F., 1999, Narratology and Biblical narratives; a practical guide, Wipf \& Stock, Eugene, OR.

Turner, D.L., 2008, Matthew, Baker, Ada, MI. (Baker exegetical commentary on the New Testament).

Viljoen, F.P., 2007, 'Fulfillment in Matthew', Verbum et ecclesia 28(1), 301-324. https://doi.org/10.4102/ve.v28i1.109

Viljoen, F.P., 2011, 'Power and authority in Matthew's gospel', Acta Theologica 31(2), 329-345. https://doi.org/10.4314/actat.v31i2.17

Viljoen, F.P., 2013a, 'Righteousness and identity formation in the Sermon on the Mount', HTS Teologiese Studies/Theological Studies 69(1), Art. \#1300, 1-10. https://doi.org/10.4102/hts.v69i1.1300 
Viljoen, F.P., 2013b, 'The righteousness of Jesus and John the Baptist as depicted by Matthew', In die Skriflig 47(1), Art. \#393, 1-8. https://doi.org/10.4102/ids.v47i1.393

Viljoen, F.P., 2018a, 'Reading Matthew as a historical narrative', In die Skriflig 52(1), a2390. https://doi.org/10.4102/ids.v52i1.2390

Viljoen, F.P., 2018b, 'The Matthean Jesus' surprising instruction to obey the teachers of the Law and Pharisees', HTS Teologiese Studies/Theological Studies 74(1), 4911. https://doi.org/10.4102/hts.v74i1.4911
Viljoen, F.P., 2019, 'The Matthean characterisation of Jesus by God the Father', HTS Teologiese Studies/Theological Studies 75(3), a5611. https://doi.org/10.4102/ hts.v75i3.5611

Von Harnack, A., 1912, “"Ich bin gekommen”: Die ausdrücklichen Selbstzeugnisse Jesu über den Zweck seiner Sendung und seines Kommes', Zeitschrift für Theologie und Kirche 22(1), 1-30.

Witherington III, B., 2006, Matthew, Smyth \& Helwys, Macon, GA. 